\title{
THE JUDICIARY-BASED SYSTEM OF CHILD SUPPORT \\ IN GERMANY, FRANCE AND GREECE:
}

AN EFFECTIVE SUGGESTION?

Helen Xanthaki ${ }^{\star}$

Proper child support payment has been defined by Martiny as payment when it is due, every time it is due and as much as is due [see Martiny, [1987] Zeitschrift für Rechtsoziologie, p.47]. Forcing reluctant parents to pay proper child support for their children is a problem common to the majority of countries around the world. The establishment of the Child Support Agency (CSA) seems to be the executive-based solution proposed by the UK government for the effective enforcement of the parents' child support obligation. However, in view of the recent criticisms of the CSA, which has been described by some as ineffective, unconstitutional and dysfunctional, one can not help but wonder if there is any benefit in the judiciary-based solution to the problem of effective enforcement of the parental child support obligation still applied in some European countries.

This paper aims to provide an answer to this question by analyzing the child support regulations in three EU member states, namely Germany, France and Greece. Reference will be made to the relevant articles of their Constitutions and Civil Codes in an attempt to present the substantive legal basis of the parental obligation to child support within these three countries. This will lead to the procedural aspect of the topic, namely to the procedure(s) under which child support can be obtained. The enforcement mechanisms of the child support order, acquired through the procedure(s) mentioned above, will be presented. This will lead to the evaluation of the effectiveness of these national provisions on the basis of the few empirical studies available for the selected countries. As the aim of this paper is to present and evaluate the court-based systems of enforcement currently in force in the Continent, a detailed analysis of the CSA and the British legal solu-

\footnotetext{
^ Helen Xanthaki, LL.B. (Athens), M.Jur. (Dunelm) is a lawyer (Athens Bar Association) and the Assistant Director of the Centre for Legislative Studies at the Institute of Advanced Legal Studies (University of London). This paper is a result of wider research on the subject of child support under the common and civil law systems conducted by Helen Xanthaki and Claire Archbold, Barrister-at-Law of the Inn of Court of Northern Ireland and Lecturer in Law at the Queen's University of Belfast. The initial research would not have been possible without the assistance of a traveling bursary from the County Antrim Jury Bursary Committee.
} 
tion to the problem of child support does not fall within the scope of this paper. In any case, the issue is adequately addressed by Archbold and Xanthaki in another publication [see Archbold and Xanthaki [1997] WJCLI].

The choice of the three jurisdictions analyzed here was not made at random. Germany and France are the two civil law countries with the highest number of divorces consistently after 1982, whereas Greece has the second lowest after Luxembourg whose tiny population justifies its position in this statistic [see Eurostat-CD, 1994].Given the high divorce rates in Germany and France, the regulations on child support in these countries are perfect examples of judiciary-based solutions proposed by countries facing an urgent need for effective child support provisions and having the resources to meet that need. The Greek provisions are an example of a judiciary-based solution proposed by the country with the lowest proportion of divorces within the EU and limited resources.

\section{Child support regulations in Germany}

In the unified Germany family, marriage and parenthood are constitutionally established and protected [see Finger, 1979]. Children within and children outside marriage now have equal rights [see par.5 of art.6 GrundGesetz]. Thus "legitimate" and "illegitimate", eheliche and uneheliche Kinder, have equal rights [see Graue, 1988:185]. Child maintenance and support within and outside marriage are the parents' natural rights and obligations, whose execution is supervised by the community [see Art.6, par.2 GG]. In fact, the positive obligation of the state is to respect the individuality and "selfresponsibility" of the family, whereas the negative obligation of the state is to abstain from any actions that would unjustifiably harm the family. Parents are considered to be the natural parents of a child born within marriage and/or the mother of a child born outside marriage [see Schmidt-Bleibtreu and Klein, 1973: p.206]. Further regulations on child support can be found in Arts.1601-1615 Bundesgesetzbuch (BGB). The reciprocal obligation of the parents to provide for their children is regulated by the general provision on the support of one's relatives [see Art.1601 BGB].

Under Art.1602 BGB support is owed only to those unable to support themselves. Thus, parental obligation for child support does not exist if the child can provide for itself. It is accepted, however, that if the parents can provide for the child, the latter need 
not use its personal income as a means of support [see Schlüter, 1992: 165; contra Pages- Cabanel, 1985: 36]. It is only when the parents are unable to provide for the child with no fault of their own that the child has the obligation to use its own income [see Art. 1603, par.2.2 BGB]. The burden of proof of the fact that the parents' income is not sufficient for their own support lies with the parents. If the child has no income at all or if the latter is insufficient for its support, the parents must provide for it, even when they are unable to support themselves. However, the child need not its personal income, when the parents fail to use their ability to earn an income [see RGJW 1917, 42; OLG Nünberg, NJW 1981, 1680]. Thus, if the parents are in a critical financial condition, they must use all their resources (even from additional secondary work, bonuses, state benefits, or money paid by third persons for the support of their own personal needs) equally for the support of themselves and their children [see BGH FamRZ 1980, 984; BGH FamRZ 1980, 771; BGH NJW 1980, 984]. This obligation applies equally to adolescent children from the present and other marriages [see Art. 1609 BGB]. Thus, the lack of personal income on behalf of the parents does not affect their obligation to financially support their children from previous marriages [see Schlüter, 1992: 166].

The content of the parents' child support obligation includes 'the costs of all needs", such as cost of food, clothes, home, medical insurance, as well as the cost of the child's spiritual, musical and professional development. The latter includes the choice of profession relative to the child's talents and abilities [see BGB FamRZ 1977, 629; OLG Hamburg, FamRZ 1986, 382; OLG Bamberg FamRZ 1988, 1087]. Children have the right to maintain the quality of life they enjoyed before their parents' divorce. The criterion for determining the sum owed as child support is the sum that the parents would have spent on the child, had their marriage remained stable. This sum is paid in advance in the form of monthly installments [see Art.1612 BGB]. Parents may determine the way in which payment will be made. In principle, parents may pay either in natura (namely by offering the child housing and caring) or by compensation (namely a sum of money). Payment in natura is acceptable, only "when its transfer is in reality and by law sufficient" for the needs of the child [see BGH FamRZ 1981, 250; NJW 1985, 1339]. It is now widely accepted that after their divorce parents can no longer pay in natura since this kind of payment is no longer sufficient for the fulfillment of the child's needs [see Graba, FamRZ 40 [1993] p.386]. Under Art.1612 BGB, the decision of the parents can be reviewed before the Vormundschaftgericht, the court which mainly deals with issues 
concerning guardianship. If this court confirms the decision of the parents, the family court must consider this decision legally binding [see BGB FamRZ 1981, 250]. Even when payment in natura is acceptable, only one of the parents may opt for it and this usually is the parent with whom the child lives. Both parents, however, are equally obliged to pay child support, as they are relatives of the same degree. The sum awarded as child support can be altered by a court decision according to the new financial obligations and income of both the parents and the children [see Künkel, FamRZ 41 [1994], p.540; Art.23 Code of Civil Procedure]. The obligation for child support ceases in the event of the child's death. However, it continues after the death of the parent [see Art.1615 BGB], since the recipients of the deceased parent's bequest also inherit the obligation for child support [see Art. 1586 BGB]. The heirs of the parent have the additional obligation to pay any interests or arrears or debts connected with child support owed by the deceased [Art.1615 BGB].

In Germany there are two types of child support: the Individualunterhalt and the Regelunterhalt, which is usually recommended by the executive authority (the Jugendamt) considered the ad hoc tutor of the child. The Individualunterhalt is calculated on the basis of the financial situation of the parent and the way of life of the child. The Regelunterhalt is regulated by a government decree and is increased every second year so as to adapt to the increasing level of needs for the maintenance of a modest way of life [see Art. 1615 BGB]. If the parental income changes after divorce, the quality of life that the child would have had changes as well; thus, the child support owed by the parents changes dramatically [see Graba, FamRZ 41, p.479]. If the parents belong to professional groups whose income is above the minimum regulated by national labour laws, the child may ask for an increase of the monthly installment to a percentage (10\% up to $100 \%)$ calculated by the court on the basis of the income of the parent [see Pages-Cabanel, 1985: 69]. The main advantage of the Regelunterhalt is that its payment can be ordered during a court trial for a related matter (i.e. recognition of fatherhood). In this case the judge calculates the sum owed as support on the basis of a relevant certificate by the Jugendamt (art.3 KJHG) and orders its payment with no additional cost for the child. Only children born outside marriage can opt for Regelunterhalt [see Maurer, FamRZ 41 [1994] p.338]

As far as the enforcement of the child support obligation is concerned, there are three systems of protection for the child: the contractual, the judicial and the administra- 
tive systems. The child may opt for a contractual agreement, thus receiving the dual protection offered by the check of legality and moral standing of the relevant agreement by the notary before whom the agreement is signed [see Art. 1934 BGB] and by the confirmation of this agreement by the court [Art. 1615 BGB]. The judicial system offers the child protection in the form of a court decision which can be directly executed against the parent. The administrative system offers the child protection in the form of benefits or compensation due to the parent's death at war, due to Nazism or during the parent's military service.

As far as the execution of the obligation is concerned, the child may opt for the acquisition of a court order allowing it to liquidate all or part of the parental property and withhold the owed amount of money as capital and due interest [see Arts.291 and 288 BGB]. Moreover, the child may choose to obtain court orders for the acquisition of a detailed report of the parent's sources of income and for direct payment from the parent's employers or debtors [see Arts. 834 ZPO; 829, 166-168 and 835 CPC]. A third, indirect option concerns the child's right to pursue payment utilizing the threat of a criminal procedure under Art. 170 Penal Code, according to which failure to pay child support constitutes a criminal offense. If the child chooses this route, it may pursue the civil execution of the parent's obligation in the criminal trial.

\section{French regulations on child support}

In France the parental obligation for child maintenance and support is regulated by Art.203 of the French Civil Code (CC), under which one of the obligations arising from marriage is the mutual obligation of the spouses to provide for the biological, financial, moral and educational development of their children. The parental obligation of child support is extended, so as to cover children born outside marriage and adopted children [see Carbonnier, 1991: 557]. In contrast with the German legal system, in France the parental obligation for child support is non-transferable. Thus, in case of death of one of the parents the obligation cases to exist and the heirs of the deceased have no obligation to continue paying child support [see TGI Bayonne, 2 oct. 1973, J.C.P. 1974, II 17604].

The obligation is non-reciprocal [see Carbonnier, 1991: 557; Guimenazanes, p.153]. It covers everything that is considered necessary for the well-being of the child [see Ass.plen. 20 juill. 1979, Bull.civ. no 6; Gaz. Pal.1979, 2.545, note Viatte]. This includes 
the provision of food, shelter, general expenses and medical insurance/expenses [see Civ. 28 fevr. 1938, D.H. 1938, 241; also see Lyon, 13 nov. 1952, D.1953, 755, note Gervesie]. It also covers exceptional expenses due to accidents, albeit under strict conditions [see TGI Seine, 19 fevr. 1966, D. 1966, 428]. For the determination of the level of child support judges consider the child's needs, the resources of the parent, as well as the legal relationship of the child with the parent (Art. 208 CC). Essentially, what is taken into account is the amount of money that the parent would have earned, had s/he used all the possible sources of income at her disposal [see Civ. 2e, 17 dec. 1965, D. 1966. 465, note R. Savatier; also see 21. janv. 1976, Bull. civ. II, no 17]. In case of children adopted through the adoption simple, the child support obligation binds exclusively the child (and its descendants) and the person who adopted it, whereas the obligation of the natural parents remains even after the adoption [see Carbonnier, 1991: 559]. Any obligations for the support of children from other marriages are taken into account, but can not be used as an excuse for the discontinuance or limitation of child support [see Civ. 1re, 17 mars 1964, Gaz. Pal., 1964, 2.56; Civ. 1re, 5 fevr. 1991, Bull.civ. I, no 43]. Payment can be made either in natura or in money. Only when payment in natura is impossible (namely after divorce) is the child offered money as a monthly allowance, at least from one of the parents [see Carbonnier, 1991: 560-561]. The obligation of the parent to pay child support and the precise sum owed to the child must be either declared by a court or agreed by the parties and signed in a contract before a notary [see Paris, 30 juin 1982, Gaz.Pal., 1982, 2. 440, note Brazier; also see Versailles, 16 dec. 1980, J.C.P. 1982. II. 19716, note Lindon]. This sum may be modified by the courts according to the needs of the child or the resources of the parent. This modification can be done automatically, if the judge includes -under Art. 208 CC- a clause d'indexation in the decision, thus rendering the amount changeable within a set period of time. This means that when an increase to child maintenance is required, the child need only acquire an order determining the precise amount of increase without any discussion on the right or not of the child to increase, since the latter would have been regulated by the initial judgement. It must be noted that the determination of a precise percentage of increase per set periods of time is no longer allowed, because of the unpredictability of the monetary depreciation [see Carbonnier, 1991: 562-563].

As far as the execution of the obligation is concerned, French law offers the child a set of five protective legal routes provided that the child has obtained a title executoire, 
namely a document that under the provisions of the Code of Civil Procedure can be used as an order to the bailiffs for the execution of the obligation in question, from the tribunal d' instance:

a) Since the courts' order for payment of child support is covered by a judicial real security equivalent to a mortgage, the child may liquidate the parent's immobile fortune (namely houses, estates, land and cars).

b) The child can pursue the "direct payment of support installments" under the Procedure de paiement direct des pensions alimentaires established by the relevant law of 2.1.1973 and the decree of 1.3.1973, thus acquiring a court decision allowing it to be paid directly by the parents' employers, debtors or even the bank with which the parent has an account.

c) The child may opt for payment by public organizations, which -after the court decision determining the parent's obligation to pay and the amount owed to the child- have the power to find the parent and enforce the court's decisions on behalf of the child. This procedure is called recouvrement par les organismes debiteurs de prestation familiales. The advantage of this procedure, introduced by Art. 293 of the law of 22.12. 1984 as modified by decree $86-1073$ of 30.9 .1986 , lies in its simplicity, since the only actions required on behalf of the child is the acquisition of a court decision and the presentation of the case to the respective public authority. All subsequent legal actions leading to the regular payment of child support are conducted by the public organization without any further requirement (financial or other) from the child itself. It must be noted that these organizations have the power to demand arrears, but their decision can be modified by a civil court [see Carbonnier, 1991: 565].

d) The child may opt for payment through the Trésor Public after the relevant order from the public prosecutor of the tribunal de grande instance of the child's domicile [see Arts. 2 and 3 of L.75-618 of 11.7.75 and d. 75-1339 of 31.12.1975]. The Trésor Public has the power to pursue, on behalf of the child, all debtors of support after the acquisition of a final court decision, provided that the child has already used in vain the first two legal routes [see Arts.1 and 15 of the law of 11.7.1975; Lindon and Bertin, 1976: 75]. The procedure is free for the child. The Treasury is paid by the parent a fee of $10 \%$ over the debt [see JO, Deb. Senat, p.2162, col.1].

e) The child has an indirect way to enforce the court's decision on child support: to threaten the parent who has failed to pay for two consecutive months that s/he will be 
brought before the criminal courts with the charge of "family abandonment" [see Art.357-2 CC].

\section{Greek regulations on child support}

In Greece child maintenance and support is regulated by Arts. 1485-1502 Civil Code (CC), which constitute jus cogens [see Kounougeri-Manoledaki, 1991: 116]. Under Art. $1485 \mathrm{CC}$ children and parents have a reciprocal obligation to support each other. Support is owed to children born within and outside marriage as well as adopted children [see 1502 CC; Koumantos, 1989: 94-95]. The conditions for the existence of the obligation are the inability of the beneficiary to provide for herself [see Art. $1468 \mathrm{CC}$ ] and the debtor's ability to pay support without taking any serious personal financial risks [see Art. $1469 \mathrm{CC}$ ]. Thus, the child must have tried in vain to find a suitable job and must lack personal income from a salary or any other resource. It must be noted that as a rule children still going to school may not be in paid employment [see AthCFI 14130/1982 EEN 50 [1983] 48; AthCA 8200/1984 Arm 39 [1985] 215; AthCA 2087/1986 NoV 34 [1986] 1242; AthCA 3956/1986 ArchN 38 [1987] 497]. Moreover, under Art.1486 (2) the adolescent child (married or single) must only make use of the interest of any earned income. The capital of the income need not be used [see Deligianni-Kousoula, 1984: 212]. After the deduction of the sum owed as child support and having tried to exploit all possible sources of income, the parent must be able to meet her own basic needs [see Grammenos, 1986: 55; AthCA 3689/1985 EllDni 26 [1985] 1169].

Under Art. 1493 CC child maintenance includes "everything necessary for the support of the beneficiary plus expenses for her development and professional and general education". This includes allowance for food, shelter, heating, electricity, water supply, clothing, medical insurance, entertainment, social events, holidays, as well as the finance of graduate, post-graduate and doctoral studies, provided that these are included in the real (not desirable) needs of the beneficiary [see Patras CA 356/1984 EEN 51 [1984] 662; Vathrakokoilis, 1989: 513; Deligianni-Kousoula, 1984: 227]. For the calculation of child support judges take into account the child's way of life and that of the members of its family. Under Art. 1496 CC support is paid in monthly installments at the beginning of each month. Child support may also be paid on a more frequent basis or in natura [see Koumantos, 1989: 120-121]. The decision on the type of support paid to the 
child (in money or in natura) lies with the parents or the courts. As a rule, after divorce the parent with whom the child lives pays in natura, whereas the other parent in money. The sum agreed by the parties or ordered by the court can be modified according to the new needs or income of the child or the parent [see Art. 1494 CC]. The obligation to support ceases to exist after the death of either the child or the parent [see Art. 1495 CC].

Many regulations of Greek law in the Civil Code and the Code of Civil Procedure (CCP) aim to protect the child and facilitate the payment of child support when the parent refuses or omits to pay. The child support claim is not seizable and can not be used by the child's debtors for the payment of its debts [see Art. 982 CCP]. Child support can neither be used to balance any other debt of the child to the parent [see Art. $445 \mathrm{CC}$ ], nor be the object of real security [see Arts.1178 and $1247 \mathrm{CC}$ ]. Another provision set to protect the child refers to the nullity of the resignation from any claim for support for the future [see Art. 1499 CC]. Moreover, in all trials on child support, the parent pays in advance for any court expenses occurred, irrespective of the outcome of the case [see Art. $173 \mathrm{CCP}]$.

As far as the execution of the obligation is concerned, any disputes concerning child support are judged by the Single-member Court of First Instance of the child's domicile under the special procedure of Art.681 CCP [see Art.16 no 10 CCP; Sinaniotis, 1984: 372-378]. Support disputes can also be judged by the Multi-member Court of First Instance if they are judged in the same trial with any other dispute on parenthood. This provision is particularly beneficial for the child, since no expenses are needed for the second trial [see Kounougeri-Manoledaki, 1991: 147; AthS-mCFI 19180/ 1986 D 18 [1987] 225]. Thus, the child may choose to bring the parent before the court and ask the court to order payment within a specified period of time. It must be noted that with a temporary court decision on interim measures based on the mere suspicion that support is owed, the child can be awarded support within three to four days. If the parent fails to pay, this decision can be used as the basis for an "executionary" decision, which allows the bailiffs to liquidate all or some of the parent's immovable assets and give the owed amount to the child. The child may also opt for the partial seizure of the parent's salary, pension, other income or social security benefits, which allows it to receive direct payment from the parent's employer, debtor or the social security authorities [see Art. 982 $\mathrm{CCP}$. The child has a third indirect way of forcing the parent to pay child support: the threat that the parent will be reported to the respective Public Prosecutor for committing 
the criminal offense of "failure of one's obligation to pay support" which is regulated by Art. 358 of the Penal Code. It should be noted that the offense carries a more severe penalty, if the child is an adolescent and has suffered bodily harm [Art. 312 PC], or if the parent has left the child helpless with the purpose of harming the child's health [Art. 308 PC]. It should also be noted that under Art. $1501 \mathrm{CC}$ the public prosecutor has the obligation to assist the child free of charge in any way possible for the enforcement of the court decision on child support This procedure offers only limited protection to the child [see Koumantos, 1989: 137; Vathrakikoilis, 1989: 531].

\section{An Evaluation of the German, French and Greek provisions}

From the analysis of the provisions on child support within the three selected countries it has become clear that their regulations concerning the nature of the child support obligation, its content, extent, enforcement and execution are very similar, in that they rely on a judiciary-based system of determination, execution and enforcement of child support payments. This similarity is quite surprising in view of the fact that the extent of the problem and the resources available for its solution differ considerably within these countries. Indeed, Germany and France have the highest proportions of children below 16 living in single parent families amongst the civil law countries of the EU, whereas Greece has the lowest at less than $4 \%$ with no considerable rise since the 1970s. The overall highest belongs to the UK with 15\% [see Doing Business in Europe No. 286 [1996] p.3; Roll, 1991: 69]. Greece also holds the lowest percentage of children born outside marriage within the EU at only $2 \%$ compared with the highest of $40-50 \%$ in Denmark [see Roll, 1991: 63]. Moreover, since 1980 Germany and France have been consistently spending the most for the social protection of the family within the EU, whereas Greece has been consistently spending the least. By function in Mio ECU at constant 1985 prices, which renders the sums comparable as they do not refer to national currency rates, in 1990 Germany spent 19,284.4, France 18,386.1 and Greece 100. In 1991 Germany spent 22,516.7, France 18,126.3 and Greece 93.3, whereas -according to

the latest available figures- in 1992 Germany spent 23,148.7, France 18,665 and Greece 88.1 [see Eurostat Statistical Documents, Series 3C, 1994].

The introduction of similar provisions by three countries with totally different needs and resources may be seen to indicate that the judiciary-based system is quite suit- 
able for the effective enforcement of child support obligations irrespective of the frequency of the problem and possible financial considerations. Such an argument, however, would ignore the considerable influence of French and German law on Greek law. Thus, for the accurate evaluation of the system of child support in the selected countries, further analysis on its effectiveness in practice is necessary. It must be noted, however, that such an analysis faces the inherent problems of any empirical research on issues of family law (such as diversity in the factors measured and the measures used), as well as the additional particular problems of lack of data or the existence of clashing data [see Martiny, 1987: 25]. Neither of the Justice Ministries of the selected countries have conducted or are aware of similar research [see Bundesministerium der Justiz document I A 3-3470/2 II-11 1563/96 of 30 December 1996; also see Ministère de la Justice; Service des affaires européenes et internationales document C:\OFFICE $\backslash$ WPWIN $\backslash A L A I N \backslash C O U R$ DIV $\backslash$ XANTHAKI of 30 October 1996; also Elliniko Ypourgeio Dikaiosinis, document of 16 January 1997].

Family in most civil law countries is protected by the constitution. Consequently, the right of a child to be supported by its parents and the obligation of the latter to support their children are constitutionally introduced and protected. Any limitation, let alone abolition, of this right and duty can only occur following the complicated procedure of constitutional reform. Any other source of law (legislative or administrative) limiting or abolishing the right and obligation to child support would be unconstitutional and, therefore, lack legal value. The constitutional protection of the right and obligation to child support indicates the fundamental importance awarded by these three countries to the prompt payment of child support to children who are entitled to it. It also introduces the obligation of the state to ensure that this right is effectively realized.

In the countries presented here child support is owed both before and after the parents' divorce. Thus, child support is a right and obligation which starts as soon as the child is born and exists irrespective of any possible changes in the relationship between the parents. For the duration of parental marriage child support is paid by both parents in natura. After divorce the law recognizes the need for the regulation of a different form of payment, since in natura payment by both parents becomes impossible. In principle, the parents' right and obligation to child support is not affected by subsequent families or by their inability to provide for their children. However, the attempt of the legislator to guarantee a continuum in the level of child support, even in cases where the social envi- 
ronment of the family is not the same, is not always successful in practice. Often after divorce, and especially after the creation of a new family, and the subsequent division of parental property in multiple shares parents can only afford a very low level of support, which does not necessarily reflect the amount needed for the fulfillment of even the basic needs of each of their children.

Although relevant data, in comparable format, are scarcely available, the existing figures demonstrate that child maintenance payments in the three selected countries are quite low in practice. A recent survey conducted in France concerning the child support payments ordered by the Pau Court of Appeal in 1994 indicate that these range from as little as 200 francs per month, paid for the support of two 14 and 17-year-olds to a 46year-old unemployed mother without personal income by the 42 -year-old unemployed father without income, to up to as much as 1,600 francs per month paid for the support of two children (one of whom was already an adult) to a mother with a monthly income of 2,000 francs by the father whose monthly income was 13,700 francs [see Revue Jurisprudence d'Aquitaine 1 [1995] 1]. Although the research was conducted on divorce par faute, these figures are quite representative of the practice of French courts as the legal basis for the divorce bears no effect on the sum awarded as child support. These data can be better evaluated if read in conjunction with another French survey, which indicated that the lone mothers' average share of disposable income for support was only $13 \%$. In fact, the Bundesministerum der Justiz expressed the view that such statistics or surveys would not be possible, as most child support payments follow private agreements and private payments [see document I A 3-3470?2 II - 11 1563/96 of 30 December 1996].

A similar German survey has shown that only $15 \%$ of lone mothers use child support as their only or main source of income, despite the fact that $75-90 \%$ of parents do pay child support either following a private agreement $(50 \%)$ or a court order $(50 \%)$ [see Roll, 1991: 71; Maclean, 1992, p.353; Willenbacher and Vögeli, 1992: 237]. Data on the level of child support awarded in Germany is not available. The recently amended Düsseldorfer Tabelle and the 1996 guidelines to the judges of the Oberlandesgerichte indicate that for the calculation of child support payments German judges should take into account the level of parental income after the addition of all sources of income (including benefits) and the subtraction of taxes, debts, rent or professional expenses (which can only be 90-120 marks per month). German judges must also take into account 
that the minimum sum covering a child's basic monthly needs is approximately 900 marks in Frankfurt/Main and Jena, 1,100 in Hamburg and 1,085-1,360 in Rostock [see Düsseldorfer Tabelle, Report No 66 (December 1995, Bundesministerium der Justiz, Bonn; Unterhaltsrechtliche Leitlinien und Tabellen der Oberlandesgerichte ab 1.1.1996 in Unterhaltsrecht, Report No 67, January 1996, Bundesministerium der Justiz, Bonn]. Although the system seems to be sound in theory, the German government has accepted that in practice the final sum awarded as child support is often much lower than the social security benefits available for this child [see the Answer of the Bundesregierung to the Question of SPD Members of the German Parliament Dr Marliese Dobberthien, Margot von Renesse and Hanna Wolf on "Unterhaltsplicht und Unterhaltflucht von Vätern und Müttern" in Deutscher Bundestag 12. Wahlperiode Drucksache 12/5052 of 28.05.1993, question 1].

The link of child support to parental income seems to be unfair to the child, who without having any option on arriving in this world may end up with a family unable to provide for it. However, any evaluation on the effectiveness of the judiciary-based system in the three selected countries would be incomplete without reference to possible assistance provided to the children from the state. Indeed, in all three chosen countries children may make use of social security regulations introducing their right to benefits, to a percentage of parental pension in case of parental death, or even to specific benefits for exceptional cases (parental death in war etc.).

This social security system seems to provide a sound safety net for the financial survival of the child, at least in theory. The question here is whether the system works equally well in practice. According to the last available data, in 1992 the family allowance received per child up to 18 years in ECUs at constant 1985 prices was 38 in Greece, 1,356 in France and 1,933 in Germany. These sums reflect a minimal increase compared to the last decade's figures in Germany and France, which in 1983 awarded 1,254 and 1,250 accordingly, whereas they represent a dramatic fall in comparison to the 75 ECUs awarded in Greece in 1983. Moreover, the family benefit (which constitutes the main assistance provided by the state to children after divorce in the three selected countries) received per child in 1992 was 5 in Greece, 125 in France and 174 in Germany compared to 12, 152 and 149 accordingly in 1983 [see Eurostate Yearbook 1995, First Edition, 1995, Office for Official Publications of the EC, Luxembourg]. These figures indicate 
that the levels of social security benefits, which in practice mainly involve the family benefit, are in practice quite low.

A better picture for the evaluation of the aid to children in the selected countries can be drawn, when all relevant provisions on the welfare of lone parents and their children are taken into account. Indeed, the evaluation of the level of state assistance to children after the divorce of their parents would be incomplete, if relevant provisions falling within other areas of law but still contributing to the financial situation of the child were not taken into account. Germany and France allow tax relief for lone parent families, as well as arrears in the payment of child support which in 1992 amounted to 81-143 ECUs for children under 12 in Germany and to 64 ECUs in France. This option, however, is used by a relatively small number of children. In 1991 in Germany only 134,154 children were making use of this facility, a percentage of only $33,6 \%$ of the total of 399,000 children below 6 living in lone-parent families [see the Answer of the Bundesregierung to the Question of SPD Members of the German Parliament Dr Marliese Dobberthien, Margot von Renesse and Hanna Wolf on "Unterhaltsplicht und Unterhaltflucht von Vätern und Müttern" in Deutscher Bundestag 12. Wahlperiode Drucksache 12/5052 of 28.05.1993, questions 7 and 8]. It must also be noted that from 1.1.1996 this sum has gone down from 219-353 marks per child in 1995 to 214-324 marks [see BMFuS, 1996; BMFG, 1996: 34]. Moreover, as shown above, all three countries offer some social security benefits to minor children irrespective of the total family income, whereas France and Greece offer additional benefits for low-income families with children [see Neubauer, 1993: 431]. Thus, in France there is a means-tested benefit paid to lone parents whose child is under the age of 3 , a restriction which excludes $90 \%$ of lone parents [see Roll, 1991: 73]. In Greece an additional means-tested benefit is awarded exclusively to those in employment or in receipt of social insurance benefit [see Roll, 1991: 74].

From the relatively low levels of general social aid offered to children living in lone-parent families and from the fall in the sums awarded to these children in Greece and their minimal rise in Germany and France, it becomes clear that in the selected countries the state attempts to urge the child to pursue the payment of support by other sources. It is true that in the selected countries, if parents are unable to support their children, the latter have the right to seek maintenance by the members of the wider family, such as grandparents or great-grandparents. If these are equally unable to provide for the child, the latter can turn to the parent's debtors and demand direct payment from 
them. The extension of the child support obligation to the parents' relatives and debtors reflects the perception of child support in the three selected jurisdictions as a matter which concerns not only the immediate, but also the wider family of the child. However, at the same time it is a clear indication of the will of the legislator to achieve effective payment by the family itself, thus relieving the state from payment, where possible.

Payment of child support by members of the family, rather than the state, could result in the children's exploitation and manipulation to agree to conditions which are not to their best interests. This is why in the three selected countries the amount owed for child support can only be regulated by the civil courts, which either determine the precise amount owed on the basis of the particular circumstances of the family involved, or validate the agreement reached by the interested parties before a notary.

In view of the traditionally long period of time required for the completion of civil proceedings in the three countries presented here, especially when appeals and cassations are requested by either parties, one could easily conclude that the protection of the child in these countries is ineffective, at least time-wise. However, the introduction of interim measures, which guarantee the acquisition of a judicial order for the payment of child support within days from the submission of the relevant application provides for the situations where reluctant parents attempt to postpone the relevant court decision on technical or legalistic grounds.

Yet, the acquisition of a court order does not always ensure prompt payment of child support. The three selected jurisdictions attempt to ensure prompt payment through the introduction of various regulations from different fields of law. Thus, along with the introduction of payment though the liquidation of parental property, or through the direct payment from the parents' debtors, in France and Germany the payment of child support may be pursued by the Trésor public or other organizations set up in aid of the child morally, legally and financially until the final execution of the child support order.

Moreover, and possibly even more importantly, in all three countries presented here the legislator has criminalised the parental failure or omission to pay child support. The latter may result to the imprisonment of the parent involved and to a court order for the payment of additional compensation to the children. In theory this is an invaluable weapon for the children who wish to persuade their parents to pay child support regularly. According to the criminal procedure regulations, similar in all three selected countries, the child may request from the public prosecutor of the court of its residence to or- 
der the police to find the parent and bring her before the public prosecutor. In this search, the police have the strong help of the parent's identification card number, which serves to trace the parent, as it is used for employment purposes, the cashing of benefits, the lodging of a bank account, the withdrawal of funds, the renting of accommodation, the installation of water, telephone and electricity supplies therein, for marriage or divorce purposes and even for the issue and use of a valid passport.

If the police find the parent, s/he is brought before the public prosecutor and is advised to proceed with payment within a set period of time or criminal proceedings are initiated. If the police fail to find the parent in question, the children may still sue the parent. In this case her referral to the criminal courts will be announced in public and the parent will be judged in absentia. Any convictions are included in her criminal record, which is also used for employment purposes even in private posts and for exiting the country. Police in all parts of the country are notified of the conviction and begin pursuit. In theory, the threat of criminal proceedings seems so menacing, that the parent would be expected to rush to pay before the matter reaches the criminal courts. The question is whether this is true in practice.

Legal-sociological research has shown that the constant threat of pursuit by the police and the courts does lead most parents to the payment of child support [see Martiny, 8 [1987] Zeitschrift für Rechtsoziologie, p.51]. The only available figures for Germany show that the number of parents threatened with criminal court proceedings, that is the number of infringements of the child support obligation reported to the police, was 10,886 in $1990,14,259$ in 1991 and 14,639 in 1992. Of those only 3,952 were finally convicted in 1990, whereas 1,426 accepted to pay during, that is before the end of, the criminal proceedings. More recent figures are not available [see the Answer of the Bundesregierung to the Question of SPD Members of the German Parliament Dr Marliese Dobberthien, Margot von Renesse and Hanna Wolf on "Unterhaltsplicht und Unterhaltflucht von Vätern und Müttern" in Deutscher Bundestag 12. Wahlperiode Drucksache $12 / 5052$ of 28.05.1993, question 12]. The small number of parents finally convicted by the German criminal courts indicates that our initial hypothesis on the effectiveness of the threat of criminal proceedings is correct. Most parents seem to pay either before or during such proceedings, so as to avoid the serious consequences of a conviction.

In Greece 227 men and 2 women were sentenced for failure to pay support in 1990. Of those 1 was sentenced to a fine, 42 received a jail sentence of up to 1 month, 51 
of 1-3 months, 78 of 3-6 months, 51 of 6-12 months and 6 of more than 12 months [see Justice Statistics of the Year 1990, 1994, Hellenic National Statistics Service, Athens, p.58]. In 1992, 148 men and 1 woman were convicted, of which none was sentenced to a fine, 32 were sent to jail for a period of less than 1 month, 21 between 1 and 3 months, 45 between 3 and 6 months, 47 between 6 and 12 months and 3 for more than 12 months [see Justice Statistics of the Year 1992, 1995, Hellenic National Statistics Service, Athens, p.58]. These figures should be read in conjunction with the available data on the civil justice system concerning the number of civil proceedings for "financial claims within the family", which include the number of child support disputes reaching the civil courts. In 1990, 1,967 claims were brought before the Greek Courts of First Instance of which 1,638 were accepted by the judges [see Justice Statistics of the Year 1990, p.27]. In 1992, out of 1,454 claims 1,214 were accepted. The small number of convictions for failure to pay child support in comparison with the number of civil litigation on the same issue indicate that also in Greece the threat of a criminal conviction seems to be producing results. It seems that most parents tend to settle their debts on the basis of civil court orders and, even if they may need the threat of criminal proceedings as a means of persuasion for the payment of their debts, they finally choose to pay before the end of any criminal trial. France has just began compiling data on the issue.

It would therefore be fair to state that in the three selected countries the judiciarybased system of child support enforcement the child usually receives relatively low levels of child support by the parent. Should the latter fail to pay, either at all or regularly, the child is paid by the state. However, the analysis of the levels of child support offered by the state and the comparison between the recent figures and the levels of child support in the 1980s indicate that the current aim of the social security provisions is to ensure that the child will be able to survive, but that any hope for realistic financial aid for its basic needs does lie with the parent and the wider family. In order to aid the child to achieve payment by the parent all three states have criminalised the failure to pay child support. Reference to the relevant available figures indicate that most cases of child support disputes are resolved without the need, or at least before the end, of criminal proceedings.

Moreover, despite the complex and increased protection offered to the children's right to child support, there are still cases where the latter is not paid [see Martiny, 8 [1987] Zeitschrift für Rechtsoziologie p.48]. There are always parents who do not pos- 
sess personal property, or who transfer their property to trusted friends (boy/girlfriends, lawyers or other). There are parents without debtors and parents who have been or are already in jail and do not perceive imprisonment as a necessarily bad fate. Moreover, there are still parents who need constant "reminders" of their moral and legal obligation to provide for their children after the end of their marriages or relationships. Thus, in 1990 in Greece 65 convicted parents relapsed within 5 years of the initial conviction, whereas 52 relapsed in 1992 [see Justice Statistics, p.104]. Moreover, there are also children and guardians who are unfamiliar with their rights, as there are children who hesitate to pursue the matter of child support vigorously and children who would never send their parents to jail. These are some of the cases for which these judiciary-based systems continue to be ineffective.

The question is, whether this ineffectivess is due to the inability of judiciarybased systems to provide for the needs of children in cases such as those mentioned in the last paragraph. If so, would a change in the current legislation of child support assist children in their quest to enforce their legal, constitutionally introduced, right to survival in dignified circumstances? Should countries of the judiciary-based tradition, such as those analyzed here, resign to the ineffectiveness of their national laws and seek a solution to the current situation in the change of the legal framework in which enforcement of child support payment is sought? The reception of the CSA, as a representative of executive-based systems, in the UK and the evaluation of its effectiveness in the relevant academic writings demonstrates that executive-based systems do not provide full proof solutions. Moreover, the analysis of the three judiciary-based systems analyzed in this article clearly show that the majority of children have adequate legal weapons with which they may force their parents to fulfil their obligation to child support. In fact, if parents fail to comply with their duty to pay child support, children can turn to parental debtors and employers, to the wider family, to the state -and ultimately- to the criminal law mechanisms of their legal system. In most cases, these concentric safety-nets must be considered, and usually are, adequate for the protection of the child. Thus, without neglecting the need for the introduction of higher levels of child maintenance payments and the ever present scope for amelioration of the relevant legal provisions to take into account the increasing needs of children resulting from constant social and financial changes within each state, it would seem that the problem of effective enforcement of 
proper child support payment does not lie with an inherent radical inadequacy of the legal framework in which such payment of child maintenance is sought.

Leaving the sentimental dimension of the problem aside, the issue of proper payment of child support seems to be quite similar to the problems surrounding payment of any type of debt: no matter how complex and developed the relevant legal provisions are, no matter which is the nature of the legal system involved (civil or common, judiciary or executive-based), there will always be cases and ways under which payment will be avoided. It would seem therefore that the solution to the problem of effective child support payment, at least in the three jurisdictions referred to here, does not lie with the introduction of more or different legislative constructions, but with the education of parents who should realize that children, and the obligations deriving from their arrival to this world, are not just for Christmas: they are for life. Even after divorce.

\section{References}

Archbold C. and Xanthaki H. (1997), "Some European Perspectives on the UK Child Support Agency" Web Journal of Current Legal Issues

BMFuS (1996), Der Unterhaltsvorschuss: Eine Hilfe für Alleinerziehende, Bonn, Bundesministerium für Familie und Senioren

BMFG (1996), Sozialhilfe: Ihr gutes Recht, Bonn, Bundesministerium für das Gesundheit

Carbonnier J. (1991), Droit Civil: La Famille, Paris, Presses Universitaires de France

Deligianni-Kousoula E. (1984), Family Law, Athens, Sakkoulas

Doing Business in Europe (1996) No. 286

Eurostat Statistical Documents, Series 3C (1994), "Social Protection: Expenditure and Receipts", Luxembourg, Office for Official Publications

Finger P. (1979), Familienrecht mit familiensoziologischen und familienpolitischen Schwerpunkten, Athenaeum Verlag: Deutschland

Grammenos G., (1986), The obligation to maintenance, Athens, Sakkoulas

Guimenazanes N., "Family Law in France" in Hamilton C. and Standley K. (1998), Family Law in Europe, pp.199-231

Graba Dr H.-U. (1993), "Die Entwicklung des Unterhaltsreachts nach der Rechtsprechung des BGH”, FamRZ 40: 386 
Graba Dr H.-U. (1994), “Die Entwicklung des Unterhaltsrechts nach der Rechtsprechung des BGH im Jahr 1993”, FamRZ 41: 479

Graue E. D., "Family Law in Germany" in Hamilton C. and Standley K. (1988), Family Law in Europe, pp.199-231

Koumantos G. (1989), Family Law, Athens, Sakkoulas

Kounougeri-Manoledaki E. (1991), Family Law, Volume IIa, Thessaloniki, Sakkoulas

Künkel B. (1994), “Unterhalt und Sozialhilfe”, FamRZ 41: 540

Lahani S. (1994), The Treasury (Trésor) of France, Athens-Komotini, Sakkoulas

Lindon R. and Bertin P. (1976), Divorce 75, Paris, Librairies Techniques

Maclean M., "Background facts from country reports" in Weitzman L. and Maclean M. (1992), Economic consequences of divorce: the international perspective, Oxford, Clarendon Press, pp.345-355

Martiny D. (1987), "Des widerspenstigen Schulders Zähmung- Zur Soziologie des Unterhaltsrechts", Zeitschrift für Rechtsoziologie, 8: 24

Maurer H. U. (1994), “Kindesunterhalt im Beitrittsgebiet”, FamRZ 41: 338

Neubauer E., Dienel C. and Lohkamp-Himmighofen M. (1993), Zwölf Wege der Familienpolitik in der Europäischen Gemeinschaft, Stuttgart-Berlin-Köln, Verlag W. Kohlhammer

Pages-Cabanel L. (1985), L'Obligation Alimentaire de Droit Comparé, Paris, Institut de Reserches Juridiques

Roll J., "Lone Parents in the EC: Trends and Policies" in Kiely G. and Richardson V. (1991), Family Policy: European Perspectives, Dublin, Family Studies Centre, pp.63-77

Schmidt-Bleibtreu B. and Klein F. (1973), Komentar zum Grundgesetz für die Bundesrepublik Deutschland, Neuwind, Heman Luchterhand Verlag

Schlüter W. (1992), BGB Familienrecht, Heidelberg, C.F. Müller Juristischer Verlag

Sinaniotis G. (1984), Special Procedures, Athens, Sakkoulas

Vathrakokoilis V. (1989), Interpretation of the Civil Code: Precedents, Athens, Sakkoulas

Willenbacher B. and Vögeli W. (1998), "Child maintenance in the FRG”, Nomos, Deutschland 